JPPIPA, Vol. 3 No. 22018
Jurnal Penelitian Pendidikan IPA
http://journal.unesa.ac.id/index.php/jppipa

\title{
PENGEMBANGAN PERANGKAT PEMBELAJARAN IPA BERORIENTASI MODEL PEMBELAJARAN PEMAKNAAN UNTUK MENINGKATKAN MOTIVASI DAN HASIL BELAJAR SISWA PDF WUSTHA
}

Oleh:

Syamsudin

Sekolah Tinggi Agama Islam (STAI), Al Fithrah Surabaya, Indonesia

\begin{abstract}
Abstrak
Peningkatan kualitas pendidikan pada semua kalangan (termasuk di dalam pondok pesantren) merupakan upaya yang harus dilakukan untuk menyesuaikan perkembangan ilmu pengetahuan dan teknologi. Pemerintah melalui Kementerian Agama memberikan perhatian khusus terhadap pondok pesantren dengan mengeluarkan peraturan tentang pendidikan keagamaan islam termasuk di dalamnya Pendidikan Diniyah Formal (PDF) Wustha yang merupakan pendidikan formal setara SMP di dalam pondok pesantren. PDF Wustha dalam kurikulumnya mencantumkan pelajaran umum termasuk IPA. Namun dalam prakteknya pelajaran ini seolah hanya menjadi pelengkap sehingga motivasi dan hasil belajar siswa sangat rendah. Tujuan dari penelitian ini adalah menghasilkan perangkat pembelajaran IPA berorientasi model pembelajaran pemaknaan untuk melatih motivasi dan hasil belajar siswa. Analisis data dilakukan secara deskriptif kuantitatif-kualitatif dengan hasil implementasi: 1) keterlaksanaan pembelajaran; 2) respon siswa ; 3) aktivitas siswa ; 4) motivasi belajar siswa; serta 5) hasil belajar siswa. Penelitian ini dilakukan pada 35 siswa kelas VII PDF Wustha Al Fithrah Surabaya semester genap tahun ajaran 2017/2018 dengan rancangan One-Group Pre test and Post test Design. Analisis data dilakukan secara deskriptif kuantitatifkualitatif dengan hasil: 1) Keterlaksanaan sangat baik (skor rata-rata 3.78); 2) siswa merespon sangat positif (97.05\%); 3) Aktivitas siswa bersifat student center; 4) Motivasi belajar siswa meningkat; 5) Hasil belajar belajar siswa meningkat (N-gain 0.76). Simpulan penelitian ini adalah motivasi dan hasil belajar siswa PDF Wustha dapat ditingkatkan secara efektif menggunakan model pembelajaran pemaknaan.
\end{abstract}

Kata Kunci: Pembelajaran pemaknaan, Motivasi belajar, Hasil belajar

\section{Abstract}

Improving the quality of education in all levels (including in Islamic boarding schools) is an effort that must be made to adjust the development of science and technology. The government through the Ministry of Religion gives special attention to Islamic boarding schools by issuing regulations on Islamic religious education including Pendidikan Diniyah Formal (PDF) Wustha which is formal education equivalent to junior high school in Islamic boarding schools. PDF Wustha in its curriculum includes general lessons including science. But in practice this lesson seems to only be a complement so students' motivation and learning outcomes are very low. The purpose of this study was to produce science learning tools oriented to the meaningful learning model to train students' motivation and learning outcomes. Data analysis was carried out in descriptive quantitative-qualitative with the results of implementation: 1) the implementation of learning; 2) student response; 3) student activities; 4) student learning motivation; and 5) student learning outcomes. This research was conducted on 35 class VII students of Al Fithrah Wustha Surabaya even semester 2017/2018 academic year with One-Group Pre test and Post test Design. Data analysis was carried out in descriptive quantitative-qualitative with the results: 1) Implementation was very good (average score 3.78); 2) students respond very positively (97.05\%); 3) Student activities are student center; 4) Student learning motivation increases; 5) Student learning outcomes increase (N-gain 0.76). The conclusion of this study is that the motivation and student learning outcomes of PDF Wustha can be improved effectively using the meaningful learning model.

Keywords: Meaningful learning, Learning motivation, Learning outcomes

(C) 2018 Universitas Negeri Surabaya 


\section{PENDAHULUAN}

Peningkatan kualitas pendidikan pada semua kalangan (termasuk di dalam pondok pesantren) merupakan upaya yang harus dilakukan untuk menyesuaikan perkembangan ilmu pengetahuan dan teknologi. Pemerintah melalui Kementerian Agama memberikan perhatian khusus terhadap pondok pesantren dengan mengeluarkan peraturan tentang pendidikan keagamaan islam termasuk di dalamnya Pendidikan Diniyah Formal (PDF) Wustha. PDF Wustha adalah pendidikan yang sederajat dan memiliki kewenangan yang sama dengan madrasah tsanawiyah/sekolah menengah pertama yang diselenggarakan oleh dan berada di dalam pesantren secara terstruktur dan berjenjang pada jalur pendidikan formal (Kemenag, 2014).

PDF Wustha dalam kurikulumnya mencantumkan pelajaran umum termasuk IPA. Pendidikan IPA diharapkan dapat dijadikan wahana bagi siswa untuk mempelajari diri sendiri dan alam sekitar serta prospek pengembangannya lebih lanjut dalam menerapkannya di dalam kehidupan sehari-hari. Proses pembelajarannya menekankan pada pembelajaran penemuan konsep untuk mempelajari dan memahami alam sekitar secara ilmiah. Pendidikan IPA diarahkan untuk membantu siswa untuk memperoleh pemahaman yang lebih mendalam tentang alam sekitar (Trianto, 2011).

Observasi di PDF Wustha Pondok Pesantren Assalafi Al Fithrah Surabaya menunujukkan bahwa motivasi belajar siswa dinilai masih sangat rendah, hal ini didasarkan atas temuan penulis bahwa; 1) siswa sering terlambat masuk kelas bahkan harus ada tim khusus untuk mengarahkan siswa masuk kelas, 2) ketika diberikan tugas siswa kurang tekun mengerjakan tugas-tugas sehingga tidak terselesaikan dengan baik, akhirnya mengerjakan di kelas dan mencontoh hasil pekerjaan siswa lain yang mereka anggap bisa, 3) di dalam kelas siswa masih belum dapat mengendalikan diri masih bercanda dan mengganggu proses pembelajaran bahkan tidur di kelas, 4) siswa kurang ulet dalam menghadapi kesulitan dan malas belajar IPA. Hasil pengamatan penulis juga menunjukkan bahwa hasil belajar siswa pada pelajaran IPA masih rendah, terbukti pada nilai Ulangan Harian, Penilaian Tengah Semester, maupun Penilaian Akhir Semester nilai yang di bawah kriteria ketuntasan minimal. Padahal pondok pesantren assalafi al fithrah mencantumkan bahwa visi utamanya adalah "Mensuritauladani akhlaqul karimah baginda habibillah rasulullah SAW, meneruskan perjuangan salafus sholih, terdepan dalam berilmu dan beragama serta mampu menghadapi tantangan zaman. Oleh karena itu, perlu adanya inovasi dalam pembelajaran. Salah satunya melalui penerapan model pembelajaran pemaknaan.

Model pembelajaran pemaknaan merupakan alternatif untuk membelajarkan IPA di kelas sesuai tuntutan Kurikulum 2013 (Ibrahim, 2014). Model pembelajaran pemaknaan dapat ditelaah secara rinci yaitu model pembelajaran apabila diimplementasikan diharapkan dapat dilakukan pengembangan kecakapan hidup yang meliputi berkomunikasi, berpikir, serta penyelesaian masalah; mengefektifkan capaian akademik siswa yang terdiri atas aspek kognitif, afektif, dan psikomotorik (Ibrahim, 2008).

Fenomena alam yang sesuai pada materi pencemaran air dapat dijadikan contoh sebagai model dan dimaknai untuk mengembangkan nilainilai positif, akhlak mulia dan budi pekerti. Menurut Ibrahim (2008) " Alam menyediakan model yang dapat ditiru oleh siswa dan guru dalam membantu memaknai dan membantu siswa mengaitkan gejala alam dengan sikap positif, akhlakul karimah dan budi pekerti”. Prinsipprinsip yang mendasari model pembelajaran pemaknaan ini, menurut Ibrahim (2008) salah satunya adalah memiliki prinsip berpusat pada siswa. Prinsip berpusat pada siswa mengandung pengertian pembelajaran menerapkan strategi yang mengorientasikan siswa kepada situasi bermakna, kontekstual, dunia nyata, dan menyediakan sumber belajar, bimbingan, petunjuk bagi siswa ketika mereka mengembangkan pengetahuan tentang materi pelajaran yang dipelajarinya sekaligus keterampilan memecahkan masalah. Selain itu poin pentingnya adalah pemaknaan itu sendiri bahwa proses pembelajaran tidak diakhiri hanya dengan menarik kesimpulan dari data-data yang dihasilkan dari percobaan maupun pengamatan, melainkan dilanjutkan dengan memberi makna pada gejala yang ditemukan untuk kemudian dihubungkan dengan berbagai sikap positif dan nilai moral.

Berdasarkan uraian tersebut diharapkan siswa dapat termotivasi dan memperoleh peningkatan hasil belajar karena dalam pembelajaran IPA ternyata juga menanamkan nilai-nilai positif yang selama ini menjadi muatan utama di pondok pesantren. Hal ini sesuai dengan Peraturan Menteri Agama Republik Indonesia nomor 13 Tahun 2014 tentang Pendidikan Keagamaan Islam yang salah satu tujuannya adalah mengembangkan pribadi akhlakul karimah bagi peserta didik yang memiliki kesalehan individual dan sosial dengan menjunjung tinggi jiwa keikhlasan, kesederhanaan, kemandirian, persaudaran sesama umat Islam (ukhuwah Islamiyah), rendah hati (tawadhu), toleran (tasamuh), keseimbangan (tawazun), moderat (tawasuth), keteladanan (uswah), pola hidup sehat, dan cinta tanah air. Selain nilai-nilai tersebut pendidikan di dalam pondok pesantren harus menyesuaikan perkembangan zaman agar tidak tertinggal. 


\section{METODE}

\section{Jenis Penelitian}

Jenis penelitian ini merupakan penelitian dan pengembangan (Research and Development). Fokus penelitian pengembangan untuk menghasilkan produk tertentu dan menguji kelayakan, kepraktisan, dan keefektifan produk tersebut. Produk yang dihasilkan dalam penelitian ini berupa perangkat pembelajaran IPA berorientasi model pembelajaran pemaknaan yang meliputi Silabus, RPP, Materi Ajar, LKS, dan Instrumen Penilaian untuk meningkatkan motivasi dan hasil belajar siswa PDF Wustha.

\section{Rancangan Pengembangan Perangkat Pembelajaran}

Pengembangan perangkat pembelajaran pada penelitian ini mengadaptasi pengembangan perangkat model 4D (four $D$ model) yang terdiri dari tahap pendefinisian (define), perancangan (design), pengembangan (develop) dan penyebaran (disseminate) (Thiagarajan \& Semmel, Semmel, 1974). Selanjutnya direduksi oleh peneliti menjadi pendefinisian (define), perancangan (design), dan pengembangan (develop). Hal tersebut dilakukan karena ini masih dalam tahap pengembangan perangkat.

\section{Rancangan Implementasi Perangkat \\ Pembelajaran}

Implementasi perangkat pembelajaran ini menggunakan one group pretest-posttest design, dengan menggunakan satu kelompok subyek (Tuckman, 1978; Arikunto, 2010). Langkah pertama melakukan uji awal (pretest), selanjutnya dikenakan perlakuan dalam jangka waktu tertentu (3 kali pertemuan), kemudian dilakukan uji akhir (posttest). Gambaran implementasi perangkat pembelajaran penelitian ini adalah sebagai berikut:

Keterangan:

\section{$\mathrm{O}_{1} \times \mathrm{O}_{2}$}

$O_{1}$ adalah pretest yang dilakukan untuk mendeskripsikan hasil belajar siswa sebelum diterapkan perangkat pembelajaran IPA berorientasi model pembelajaran pemaknaan.

$X$ adalah perlakuan dengan menerapkan perangkat pembelajaran IPA berorientasi model pembelajaran pemaknaan.

$\mathrm{O}_{2}$ adalah posttest yang dilakukan untuk mendeskripsikan hasil belajar siswa setelah diterapkan perangkat pembelajaran IPA berorientasi model pembelajaran pemaknaan.

\section{Variabel Penelitian dan Definisi Operasional}

\section{Variabel Penelitian}

Variabel yang diamati dalam penelitian ini adalah kelayakan perangkat pembelajaran yang dinilai dari validitas perangkat pembelajaran, keterbacaan perangkat pembelajaran yang meliputi LKS dan materi ajar, keterlaksanaan pembelajaran, dan respon siswa. Serta motivasi belajar dari aktivitas siswa selama pembelajaran menggunakan LKS, dan hasil belajar siswa.

\section{Definisi Operasional.}

Definisi operasional variabel (karakteristik) yang diamati dalam penelitian ini adalah sebagai berikut:

a. Validitas perangkat pembelajaran.

Validitas perangkat pembelajaran merupakan kualitas perangkat yang dinilai diperoleh dari para ahli atau pakar dengan menggunakan instrumen berupa lembar validasi perangkat pembelajaran. Perangkat pembelajaran dikatakan layak digunakan apabila minimal tingkat validitas mencapai kategori valid dengan skor minimal 2,60 (Ratumanan \& Laurens, 2011).

b. Kepraktisan dalam penelitian ini meliputi:

1) Keterbacaan LKS dan Buku Siswa

a) Keterbacaan LKS

Tingkat keterbacaan LKS merupakan penilaian siswa terhadap perangkat pembelajaran berupa LKS yang diukur dengan lembar penilaian keterbacaan LKS. Tingkat keterbacaan LKS yang baik berada pada rentang 61 hingga 80 (Ratumanan \& Laurens, 2011).

b) Keterbacaan Buku Siswa

Tingkat keterbacaan Buku Siswa merupakan analisis penulis terhadap perangkat pembelajaran berupa Buku Siswa menggunakan Diagram Fry. Sehingga dapat diketahui Buku Siswa tersebut sesuai dengan tingkat umur dan tingkat kelas siswa atau tidak sesuai.

2) Keterlaksanaan Pembelajaran

Keterlaksanaan pembelajaran adalah berlangsungnya proses pembelajaran IPA berorientasi model pembelajaran pemaknaan yang dilakukan oleh guru yang dinilai menggunakan skor.

3) Respon Siswa

Respon siswa adalah tanggapan siswa yang meliputi perhatian, ketertarikan, keyakinan, dan kepuasan terhadap perangkat pembelajaran yang diukur menggunakan angket respon siswa yang dinyatakan dalam bentuk persentase.

c. Keefektifan dalam penelitian ini meliputi:

1) Aktivitas Siswa

Aktivitas siswa adalah kegiatan siswa selama proses pembelajaran menggunakan perangkat pembelajaran yang dikembangkan meliputi mendengarkan/ memperhatikan penjelasan guru, membaca materi ajar/ LKS, memperlihatkan perilaku yang tidak relevan saat pembelajaran, melakukan pengamatan/ percobaan, mengerjakan tugas, mempresentasikan hasil 
percobaan, mengajukan pertanyaan/ pendapat, mendengarkan dan menyimak presentasi. Aktivitas siswa dinilai dalam persentase menggunakan lembar pengamatan aktivitas siswa. 2) Hasil Belajar

Hasil belajar adalah nilai ketercapaian indikator pembelajaran yang diperoleh siswa dari tes hasil belajar menggunakan lembar evaluasi yang berupa tes kognitif yang dinyatakan dalam skor.

3) Motivasi siswa

Motivasi belajar dapat diartikan sebagai kekuatan (energi) seseorang yang dapat menimbulkan tingkat kemauan dalam melaksanakan suatu kegiatan pembelajaran. Indikator motivasi belajar siswa yang diamati pada siswa meliputi ketekunan menghadapi tugas, keuletan menghadapi kesulitan (tidak lekas putus asa), minat terhadap bermacam-macam masalah orang dewasa, lebih senang bekerja mandiri, cepat bosan pada tugas rutin, dan dapat mempertahankan pendapatnya Sardiman (2001).

\section{Sasaran Penelitian}

Sasaran dalam penelitian ini adalah perangkat pembelajaran (RPP, LKS, Buku Siswa, dan tes hasil belajar) yang diujicoba pada 35 siswa kelas VII tahun pelajaran 2017/ 2018 semester genap.

\section{Tempat dan Waktu Penelitian}

Penelitian pengembangan dan validasi perangkat pembelajaran dilaksanakan di Sekolah Tinggi Agama Islam Al Fithrah Surabaya dan diimplementasikan di PDF Wustha Al Fithrah Surabaya. Waktu penelitian pada semester genap tahun pelajaran 2017/ 2018.

\section{Teknik Pengumpulan Data}

Proses pengumpulan data dalam penelitian ini menggunakan beberapa teknik sebagai berikut:

1. Validasi perangkat pembelajaran

2. Pengumpulan data pada implementasi perangkat pembelajaran yang dikembangkan dengan teknik-teknik sebagai berikut:

a. Observasi

b. Angket

c. Diagram/ Grafik Fry

d. Tes

\section{Instrumen Penelitian}

Instrumen penelitian adalah alat untuk mengumpulkan data, instrumen-instrumen yang digunakan adalah sebagai berikut:

\section{Lembar Validasi Perangkat}

Lembar validasi perangkat pembelajaran digunakan untuk acuan penilaian kelayakan komponen perangkat pembelajaran yang dikembangkan. Validasi dilakukan oleh para pakar/ dosen kependidikan yang kemudian memberikan skor dan dirata-rata. Lembar validasi yang digunakan untuk mengukur kelayakan perangkat pembelajaran meliputi: a. Lembar validasi Rencana Pelaksanaan Pembelajaran (RPP), b. Lembar validasi Lembar Kerja Siswa (LKS), c. Lembar validasi materi ajar, dan d. Lembar validasi tes hasil belajar.

2. Lembar Penilaian Keterbacaan LKS

Lembar penilaian keterbacaan LKS digunakan untuk mengetahui tingkat keterbacaan LKS. Instrumen yang digunakan berupa lembar angket dengan 6 pertanyaan yang diisi oleh siswa untuk memberi koreksi mengenai keterbacaan LKS.

3. Diagram Fry

Diagram/ Grafik Fry digunakan untuk mengumpulkan data keterbacaan siswa terhadap Buku Siswa yang digunakan. Harjasujana dan Mulyati (1997) menyatakan bahwa Formula keterbacaan diagram Fry mendasarkan formula keterbacaannya pada dua faktor yaitu panjangpendeknya kata dan tingkat kesulitan kata yang ditandai dengan jumlah (banyak sedikitnya) suku kata yang membentuk setiap kata dalam wacana tersebut. Adapun bentuk dari diagram Fry disajikan pada gambar 1 .

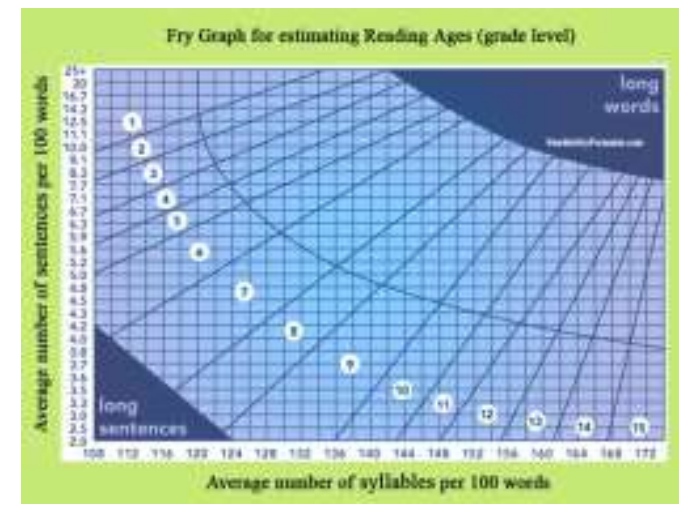

Gambar 1. Diagram Fry untuk mengukur keterbacaan siswa berdasarkan kelas, (Harjasujana dan Mulyati,1997)

4. Lembar Pengamatan
Pembelajaran
$\begin{aligned} & \text { Lembar peterlaksanaan } \\ & \text { pembelajaran digunakan }\end{aligned}$ keterlaksanaan penerapan pembelajaran IPA yang dibuat oleh peneliti dalam RPP. Instrumen yang digunakan berupa lembar ceklis yang terdiri dari kolom "ya" dan "tidak". Pengamat memberi tanda ceklis pada kolom "ya" apabila tahapan pembelajaran dilakukan oleh peneliti dan "tidak" apabila tahapan pembelajaran tidak dilakukan oleh guru. Selain itu, pengamat harus memberikan penilaian dengan rentang 1-4.

5. Lembar Pengamatan Aktivitas siswa

Lembar pengamatan aktivitas siswa digunakan untuk mengetahui kegiatan siswa 
selama kegiatan belajar mengajar dengan menggunakan perangkat pembelajaran. Aktivitas siswa diamati dan dicatat oleh dua orang pengamat pada lembar pengamatan aktivitas siswa setiap lima menit sekali.

6. Lembar Angket Respon siswa

Lembar angket respon siswa digunakan untuk mengetahui tanggapan siswa terhadap perangkat pembelajaran yang dikembangkan. Angket ini diisi secara individu dengan memberikan checklist pada kolom pilihan. Angket yang telah diisi dihitung berdasarkan kriteria.

7. Lembar Penilaian Tes Hasil Belajar Siswa

Merupakan istrumen untuk mengukur kemampuan kognitif siswa. Bentuk instrument kompetensi pengetahuan adalah berupa lembar soal yang berisi 20 butir soal pilihan ganda dengan 4 pilihan jawaban.

4) Lembar pengamatan Motivasi belajar siswa

Lembar pengamatan Motivasi belajar siswa digunakan untuk mengamati kompetensikompetensi yang dilatihkan untuk mencapai motivasi belajar siswa yang tinggi meliputi ketekunan menghadapi tugas, keuletan menghadapi kesulitan (tidak lekas putus asa), minat terhadap bermacam-macam masalah orang dewasa, lebih senang bekerja mandiri, cepat bosan pada tugas rutin, dan dapat mempertahankan pendapatnya. Motivasi belajar siswa selama kegiatan pembelajaran diamati dan diisi oleh dua pengamat. Pengamat berada dalam kelas tetapi tidak ikut terlibat dalam kegiatan belajar mengajar sehingga proses pengamatan motivasi belajar siswa tidak mengganggu proses pembelajaran.

\section{HASIL DAN PEMBAHASAN}

Pengembangan perangkat pembelajaran IPA berorientasi model pembelajaran pemaknaan bertujuan untuk menigkatkan motivasi dan hasil siswa. Berikut ini merupakan deskripsi hasil penelitian yang telah dilakukan.
1. Analisis Hasil Validasi Perangkat Pembelajaran

Hasil pengembangan perangkat pembelajaran berupa Silabus, RPP, Materi Ajar, LKS, dan Instrumen Penilaian mendaptkan skor penilaian dari validator dengan rentang 3,55-3,85 dengan kategori sangat valid (Ratumanan \& Laurens, 2006). Hasil tersebut menunjukkan perangkat pembelajaran yang dikembangkan dapat digunakan oleh guru dalam pembelajaran setelah direvisi sesuai saran dari validator.

2. Analisis Keterbacaan Perangkat Pembelajaran a. Keterbacaan LKS

Berdasarkan hasil analisis keterbacaan LKS menunjukkan bahwa $100 \%$ isi LKS menarik dan gambar/ ilustrasi dari LKS mudah dipahami, $82.86 \%$ siswa menyatakan penampilan dari LKS menarik, sedangkan $28.57 \%$ siswa menyatakan ada kesulitan dari penjelasan LKS dan $20 \%$ siswa menyatakan tidak mengerti dengan pertanyaan yang terdapat di LKS. Hal ini menunjukkan LKS dapat terbaca dan dapat digunakan untuk siswa tingkat SMP.

b. Keterbacaan Buku Siswa

Keterbacaan Buku Siswa dianalisis menggunakan Diagram Fry dengan menggunakan beberapa sampel bacaan pada Buku Siswa.

Hasil sampel tiga bagian bacaan tersebut dirata-rata jumlah kalimat dan suku kata dalam setiap 100 kata disajikan dalam Tabel 1. Berdasarkan Tabel 1 kemudian dicocokkan dengan Diagram Fry seperti pada gambar 2.

Berdasarkan analisis menggunakan diagram Fry tersebut menunjukkan bahwa Buku Siswa yang dikembangkan terbaca dan dapat digunakan sebagai panduan belajar untuk siswa kelas VIII dan VIII+1 atau VIII-1 yaitu kelas VII dan IX. Sehingga dapat disimpulkan bahwa Buku Siswa tersebut dapat digunakan oleh siswa pada jenjang SMP termasuk di dalamnya PDF Wustha.

\section{Hasil Pengembangan Perangkat Pembelajaran}

Tabel 1. Hasil analisis sampel bacaan Buku Siswa

\begin{tabular}{cccc}
\hline No. & Sampel Bacaan (100 kata) & Jumlah Kalimat & Jumlah Suku Kata \\
\hline 1. & Bagian satu (Buku Siswa Halaman 1) & 5,86 & 147,6 \\
\hline 2. & Bagian dua (Buku Siswa Halaman 7) & 6,20 & 141 \\
\hline 3. & Bagian tiga (Buku Siswa Halaman 11) & 5,95 & 140 \\
\hline \multicolumn{4}{c}{ Jumlah } \\
Rata-rata & 18,01 & 428,6 \\
\hline
\end{tabular}


Titik temu jumlah kalimat dan suku

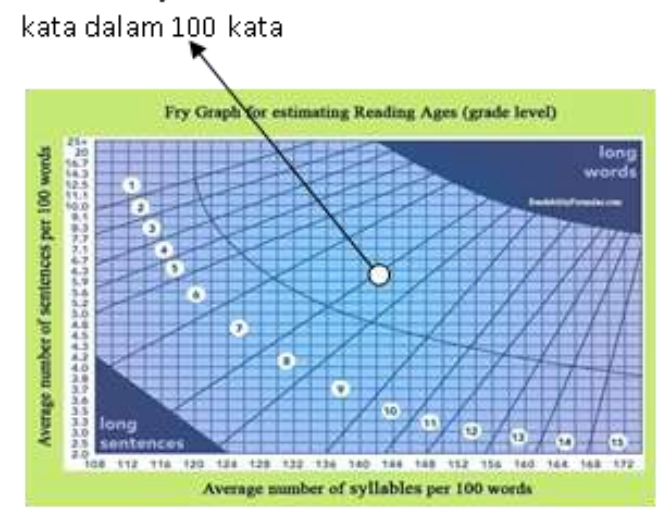

Gambar 2. Analisis Diagram Fry

Berdasarkan hasil analisis keterlaksanaan penggunaan perangkat pembelajaran yang diamati oleh dua orang pengamat, pengamatan dilakukan selama 3 kali pertemuan yang merupakan implementasi dari RPP 1, RPP 2, dan RPP 3. Berdasarkan beberapa sintaks

Hasil penilaian pengamat pada pembelajaran menggunakan perangkat pembelajaran IPA berorientasi model pembelajaran pemaknaan pada pertemuan 1 dengan skor rata-rata 3.61 dengan kategori baik (Ratumanan \& Laurens, 2011) dengan rentang penilaian yang diberikan pengamat antara 2-4. Aspek yang mendapatkan skor terendah (skor 2) oleh kedua pengamat adalah pengelolaan waktu, hal ini dikarenakan pembelajaran pada pertemuan 1 tidak selesai tepat waktu (terdapat penambahan waktu beberapa menit) yang disebabkan siswa terlalu asyik dengan pengamatan dan percobaan sehingga tidak memperhatikan batasan waktu yang telah diberikan. Hasil penilaian dua pengamat pada pertemuan 2 dengan skor rata-rata 3.77 dengan kategori sangat baik (Ratumanan \& Laurens, 2011) dan pertemuan 3 dengan skor rata-rata 3.95 dengan kategori sangat baik (Ratumanan \& Laurens, 2011). Rata-rata penilaian keterlaksanaan

\section{Hasil Uji Coba Perangkat Pembelajaran}

Uji coba dalam penelitian ini merupakan penerapan dari perangkat pembelajaran yang telah dikembangkan dan divalidasi oleh ahli. Uji coba dilakukan di PDF Wustha Al Fithrah Surabaya pada semester genap 2017-2018. Ujicoba dilakukan dalam tiga kali pertemuan yang sebelumnya dilakukan pre test dan setelah pembelajaran dilakukan post test.

1. Keterlaksanaan Pembelajaran

Keterlaksanaan penggunaan perangkat pembelajaran diamati oleh dua oang pengamat. Pengamatan dilakukan selama 3 kali pertemuan yang merupakan implementasi dari RPP 1, RPP 2, dan RPP 3.

Pembelajaran menggunakan perangkat pembelajaran IPA berorientasi model pembelajaran pemaknaan pada semua pertemuan adalah 3.78 dengan kategori sangat baik (Ratumanan \& Laurens, 2011). Instrumen keterlaksanaan RPP mempunyai rata-rata reliabilitas $99.24 \%$ dan berkategori baik (Borich, 1994).

2. Aktivitas siswa

Pengamatan terhadap aktivitas siswa dilakukan dengan menggunakan lembar pengamatan aktivitas siswa. Pengamatan terhadap aktivitas siswa dilakukan oleh 2 pengamat selama pembelajaran berlangsung yang meliputi: a. mendengarkan dan memperhatikan penjelasan guru, b. membaca LKS dan buku siswa, c. mengajukan pertanyaan atau pendapat, $d$. melakukan percobaan/ pengamatan, e. mengerjakan LKS/menyelesaiakan tugas belajar, f. mempresentasikan hasil percobaan/pengamatan, g. mendengarkan dan menyimak presentasi, dan h. memperlihatkan perilaku tidak relevan dengan pembelajaran. Adapun hasil pengamatan aktivitas siswa dapat dilihat pada Tabel 2.

Tabel 2. Persentase aktivitas siswa

\begin{tabular}{|c|c|c|c|c|c|}
\hline \multirow{2}{*}{ No. } & \multirow{2}{*}{ Aspek yang diamati } & \multicolumn{3}{|c|}{ Frekuensi (\%) } & \multirow{2}{*}{$\begin{array}{l}\text { Rata- } \\
\text { rata }\end{array}$} \\
\hline & & P1 & $\mathbf{P 2}$ & P3 & \\
\hline 1. & Mendengarkan dan memperhatikan penjelasan guru & 10 & 10 & 9,4 & 9,8 \\
\hline 2. & Membaca LKS dan buku siswa & 10 & 14,4 & 10,57 & 12,48 \\
\hline 3. & Mengajukan pertanyaan atau pendapat & 15,67 & 14 & 13,14 & 13,57 \\
\hline 4. & Melakukan percobaan/ pengamatan & 25 & 25,7 & 29,3 & 27,5 \\
\hline 5. & Mengerjakan LKS/menyelesaiakan tugas belajar & 16,57 & 15 & 15,96 & 15,48 \\
\hline 6. & Mempresentasikan hasil percobaan/pengamatan & 10,11 & 10 & 10 & 10 \\
\hline 7. & Mendengarkan dan menyimak presentasi & 9,46 & 9,44 & 9,77 & 9,60 \\
\hline 8. & Memperlihatkan perilaku tidak relevan dengan pembelajaran & 3,19 & 1,46 & 1,86 & 2,17 \\
\hline
\end{tabular}

Keterangan: P1 = Pertemuan 1; P2 = Pertemuan 2; P3= Pertemuan 3 
Berdasarkan data pada Tabel 2 didapatkkan persentase tertinggi pertemuan 1, 2 dan 3 yakni aktivitas melakukan pengamatan/ percobaan dengan rata-rata $27,5 \%$ dan mengerjakan LKS/ menyelesaiakan tugas belajar dengan rata-rata $15,48 \%$ dari total keseluruhan aktivitas. Sedangkan persentase terendah pertemuan 1, 2, dan 3 yakni pada aktivitas memperlihatkan perilaku yang tidak relevan saat pembelajaran 3. Hasil Belajar Siswa

Nilai pre test digunakan untuk mengetahui aspek pengetahuan awal siswa. Nilai post test yang diperoleh siswa menggambarkan tentang hasil belajar pengetahuan siswa setelah mengikuti pembelajaran IPA berorientasi model pembelajaran pemaknaan. Pada saat pre test 4 dari 35 siswa tuntas secara individu, ketuntasan klasikal sebesar $11.43 \%$ yang artinya secara klasikal kelas belum dapat dikatakan tuntas karena ketuntasan klasikalnya kurang dari $75 \%$ seperti yang ditetapkan oleh sekolah terkait. Setelah pembelajaran nilai yang diperoleh siswa mengalami peningkatan secara signfikan, dengan rata-rata $2,17 \%$. Hal ini menunjukkan bahwa siswa dalam kegiatan pembelajaran berada di lingkungan sosial, mereka terus menerus belajar melalui interaksi dengan orang lain di sekitar mereka. Vigotsky berpendapat bahwa perkembangan proses hidup bergantung pada interaksi sosial dan pembelajaran sosial berperan penting untuk perkembangan kognitif (Kuhlthau \& Todd, 2008). ketuntasan klasikal mencapai 100\%. Hal ini menunjukkan bahwa penerapan hasil pengembangan perangkat pembelajaran dapat meningkatkan ketuntasan indikator pembelajaran aspek pengetahuan yang juga didukung oleh perhitungan $\mathrm{N}$-gain rata-rata sebesar 0,76 dengan kriteria tinggi (Hake, 1999).

4. Motivasi belajar siswa

Penilaian motivasi belajar siswa dinilai berdasarkan hasil pengamatan selama pembelajaran berlangsung. Hasil analisis ketercapaian aspek belajar dapat dilihat pada Tabel 3.

Tabel 3. Motivasi belajar siswa

\begin{tabular}{|c|c|c|c|c|}
\hline \multirow{2}{*}{ No. } & \multirow{2}{*}{ Indikator Motivasi } & \multicolumn{3}{|c|}{ Ketuntasan (\%) } \\
\hline & & Pertemuan 1 & Pertemuan 2 & Pertemuan 3 \\
\hline 1. & Tekun menghadapi tugas & 70 & 84 & 85 \\
\hline 2. & $\begin{array}{l}\text { Ulet menghadapi kesulitan (tidak lekas } \\
\text { putus asa) }\end{array}$ & 75 & 84 & 87 \\
\hline 3. & $\begin{array}{l}\text { Minat terhadap bermacam-macam masalah } \\
\text { orang dewasa }\end{array}$ & 70 & 98 & 100 \\
\hline 4. & Senang bekerja mandiri & 70 & 84 & 98 \\
\hline 5. & Cepat bosan pada tugas rutin & 80 & 84 & 90 \\
\hline 6. & Dapat mempertahankan pendapatnya & 65 & 86 & 100 \\
\hline
\end{tabular}

Berdasarkan data pada Tabel 3 didapatkkan persentase motivasi belajar siswa meningkat. Hal ini menunjukkan bahwa penerapan hasil pengembangan perangkat pembelajaran IPA berorientasi model pembelajaran pemaknaan dapat digunakan untuk meningkatkan motivasi belajar siswa

5. Respon Siswa

Berdasarkan hasil analisis respon siswa terhadap pengembangan perangkat pembelajaran (yang meliputi: buku siswa dan lembar kegiatan siswa), serta pelaksanaan pembelajaran IPA berorientasi model pembelajaran pemaknaan secara rata-rata didapatkan hasil bahwa sebanyak 97.05\% siswa merespon sangat positif dengan kriteria sangat kuat (Riduwan, 2010).

\section{SIMPULAN DAN SARAN}

\section{Simpulan}

Berdasarkan hasil penelitian yang meliputi analisis, diskusi, dan pembahasan, maka dapat dibuat simpulan bahwa perangkat pembelajaran IPA berorientasi model pembelajaran pemaknaan yang dikembangkan sudah valid, praktis, dan efektif untuk meningkatkan motivasi dan hasil belajar siswa PDF Wustha.

\section{Saran}

Berdasarkan pada hasil penelitian yang telah dilakukan, maka disampaikan saran-saran sebagai berikut:

1. Pembelajaran IPA berorientasi model pembelajaran pemaknaan memerlukan waktu lama sehingga disarankan pada penelitian lebih lanjut perlu memperhatikan persiapan dan waktu pelaksanaan pembelajaran, supaya proses pembelajaran dapat berlangsung dengan baik karena banyak waktu yang diperlukan 
2. untuk siswa berdiskusi dan mengerjakan kegiatan observasi.

3. Pengembangan perangkat pembelajaran perlu memperhatikan penggunaan bahasa dan tingkat kesulitan materi yang harus disesuaikan dengan tingkat kemampuan dan tingkat kelas siswa.

4. Secara keseluruhan pengembangan perangkat pembelajaran IPA berorientasi model pembelajaran pemaknaan dapat meningkatkan motivasi dan hasil belajar siswa sehingga diharapkan dilakukan penelitian lanjutan pada materi lain.

\section{DAFTAR PUSTAKA}

Arikunto, suharsimi. (2010). "Prosedur penelitian". Jakarta: Rineka Cipta.

Borich, G. (1994). Observation skill for effective teaching. New York: Mac Millan Publishing Company.

Hake. (1999). Analyzing change/gain scores. Tersedia online: http://www.physicsindiana.edu/sdi/Anal yzing-Cange-Gain.pdf.

Harjasujana, A.S dan Yeti Mulyati. (1997). Membaca 2. Jakarta: Departemen Pendidikan dan Kebudayaan.

Ibrahim, Muslimin. (2008). Model Pembelajaran IPA Inovatif Melalui Pemaknaan. Jakarta: Tim Peneliti Balitbang.
Ibrahim, Muslimin (2014). Pembelajaran Sains di Sekolah Dasar Berbasis Kurikulum 2013. Premiere Educandum. Vol 1 no 1 (2014). Tersedia online http://id.portalgaruda.org/?ref=browse $\& \bmod =$ viewarticle $\&$ article $=359743$

Kementerian Agama Republik Indonesia. (2014) Peraturan Menteri Agama Republik Indonesia Nomor 13 tahun 2014 Tentang Pendidikan Keagamaan Islam. Jakarta. Kemenag.

Kuhlthau, C.C.and Todd. R.J.(2008). Guided inquiry. (Online). Tersedia. www. icwc.wikispaces.com/file/view/Guided +Inquiry.doc. Diakses 6 januari (2014).

Ratumanan, G.T. dan Laurens. (2011). Evaluasi hasil belajar pada tingkat satuan pendidikan. Surabaya: Unesa Unversity Press.

Riduwan. (2010). Skala Pengukuran VariabelVariabel Penelitian. Bandung: Alfabeta

Sardiman, A.M. 2001. Interaksi dan Motivasi Belajar Mengajar. Jakarta: Grafindo.

Trianto. (2011). Model pembelajaran terpadu. Jakarta: PT. Bumi Aksara.

Tuckman, B. W. (1875). Conducting educational research; second edition. USA: Harcout Brace Jovanovich, Publisher. 